Original Research Paper

\title{
Deep Erosion by Continental Ice Sheets: A Northern Missouri River Drainage Basin Perspective: North America
}

\author{
Eric Clausen
}

Jenkintown PA 19046, USA

\section{Article history}

Received: 22-03-2018

Revised: 01-06-2018

Accepted: 11-06-2018

Email: eric2clausen $@$ gmail.com

\begin{abstract}
While accepting some erosion by continental ice sheets most geologists reject a previously proposed deep erosion by continental ice sheets hypothesis, yet common sense logic suggests continental ice sheets should have eroded much more than they are usually given credit for. Such situations arise in scientific communities when an accepted paradigm cannot adequately explain significant observable evidence. A new and fundamentally different paradigm, constructed from detailed topographic map evidence, illustrates how deep erosion (and crustal warping) by at least one continental ice sheet explains previously unexplained northern Missouri River drainage basin erosional landform origins. The new paradigm requires at least one North American continental ice sheet to have created (by deep erosion and by ice sheet related crustal warping) a deep "hole" in which the ice sheet was located. Late during that ice sheet's melt history north- and northeast-oriented valleys eroded headward from that deep "hole's" southern end to capture immense southeast-oriented icemarginal melt-water floods and to create what are today north- and northeast-oriented Missouri River headwaters and tributary drainage routes. While successfully explaining numerous previously unexplained erosional landforms the new paradigm challenges a number of commonly accepted middle and late Cenozoic geologic and glacial history interpretations.
\end{abstract}

Keywords: Deep Erosion by Continental Ice Sheet Melt Water, Erosional landform Origins, Missouri Coteau, Missouri Escarpment, New Geology Paradigm, Prairie Coteau

\section{Introduction}

Most geologists consider White's 1972 deep erosion by continental ice sheet hypothesis, which proposed that North American and northern European continental ice sheets removed several hundred meters of underlying bedrock, to be highly speculative. White's hypothesis suggests erosion was greatest near ice sheet centers and diminished in an outward direction with little or no erosion near ice sheet margins. The hypothesis was fundamentally different from what at that time was a long-held view expressed by Flint (1971) and others that continental ice sheets had not deeply eroded underlying shield areas. Papers expressing strong criticism soon appeared. For example Sugden (1976) after presenting several types of conflicting evidence concluded, "Pleistocene glacial erosion has removed no more than a few tens of meters of material from the shield areas of the Northern Hemisphere." Boulton (1987) considered the magnitude of glacial erosion proposed by White to be far too large and cited evidence obtained by Laine (1980) that suggested the depth of glacial erosion was no more than a few meters. Interestingly Boulton fails to mention Bell and Laine (1982) subsequently used seismic reflection data from continental margins and ocean basins surrounding North America to suggest Laurentide areas had been lowered by an average of $120 \mathrm{~m}$. Sugden (1978) did associate landscapes of areal scouring with basal melting that occurred under much of the Laurentide Ice Sheet's center and in places where topography favored converging ice flow and he suggested little or no sign of glacial erosion was present in northern areas like in the Queen Elizabeth Islands and on uplands associated with diverging ice flow. He also noted landscapes of selective linear erosion near the ice sheet's eastern periphery.

Much of the debate about ice sheet erosion has focused on whether the more erosion resistant Precambrian bedrock now exposed in the shield areas 
was deeply eroded and does not address younger sedimentary rocks that probably once covered shield areas and now surround shield areas. Those sedimentary strata are often considered to have never been deposited over the shield areas or to have been very thin and to have been eroded from the shield areas long before continental ice sheet development. For example, in Scandinavia Fredin et al. (2017) recently used in situ weathered bedrock, or saprolite, to suggest that, "some of the low-altitude basement landforms on and offshore southwestern Scandinavia are a rejuvenated geomorphological relic from Mesozoic times." In North America Clark and Pollard (1998) suggest that prior to the middle Pleistocene "the Laurentide ice sheet was thinner because it was underlain everywhere by a soft, easily deformable substrate and that the transition to a thick ice sheet... occurred as thick, clayey soils (regoliths)... were progressively eroded by successive glaciations."

Many workers suggest continental ice sheets did not deeply erode sedimentary bedrock units surrounding shield areas. Licciardi et al. (1998) developed numerical reconstructions of the Laurentide Ice Sheet during the last deglaciation by assuming the ice sheet had "flowed over extensive areas of water-saturated, deforming sediment (soft beds) corresponding to the St. Lawrence lowland, the Great Lakes region, the western prairies of the U.S. and Canada and the Hudson Bay and Hudson Strait regions." Such an interpretation was developed because significant segments of the modern day Missouri and Ohio Rivers are frequently considered to have formed when a continental ice sheet blocked what researchers considered to be pre-glacial north-oriented drainage systems (Thornbury, 1965) and the abandoned north-oriented valleys are now found to the north of present day north-oriented Missouri and Ohio River tributaries. North-oriented Missouri River headwaters and tributaries and abandoned extensions of their valleys to the north and east of the Missouri River have been linked to what many researchers considered to be a preglacial Bell River drainage system that drained what is today the northern and western Missouri River drainage basin to the Hudson Straits region and then to the Labrador Sea (see McMillan, 1973; Duk-Rodkin and Hughes, 1994; Cummings et al., 2012; Sears, 2013).

While rejected by most investigators common sense logic suggests the deep erosion by continental ice sheets hypothesis has some merit. Paleozoic, Mesozoic and Tertiary bedrock units surround the Canadian Shield and it is difficult to imagine any North American geologic history where at least some of those bedrock units did not once extend across the Canadian Shield Precambrian bedrock surface. If at least some layers of those younger sedimentary strata did once cover the Precambrian bedrock something has since completely removed them and continental ice sheets that were centered on the Canadian Shield represent the most likely erosion agent.
The deep erosion by continental ice sheets debate may be much more than simply a contest between two competing hypotheses, but may be raising questions about the geology discipline's accepted paradigm's ability to explain large-scale erosional landform evidence. The overwhelming rejection of the deep erosion by continental ice sheets hypothesis may be a sign the accepted geology paradigm does not adequately explain some significant evidence.

Thomas Kuhn (1962) in his book "The Structure of Scientific Revolutions" describes situations where a scientific discipline's accepted paradigm cannot adequately explain observable evidence. According to Kuhn such situations are scientific crises and are eventually resolved in one of three ways: the accepted paradigm eventually explains the unexplained evidence and the accepted paradigm continues without serious interruption, the crisis persists and the unsolved problems are identified and labeled for future study, or "the crisis may end with the emergence of a new candidate for paradigm and with the ensuing battle over its acceptance." Paradigms, according to Kuhn, are frameworks of ideas and rules used by a scientific discipline to govern that discipline's research efforts. Kuhn further argues that paradigms by themselves are neither correct nor incorrect, but some paradigms explain more evidence and open up more research opportunities than others. In other words a scientific discipline should judge a new paradigm on its ability to explain previously unexplained evidence and also by the new paradigm's ability to open up previously unrecognized research opportunities.

The study reported here used detailed topographic maps, although was only initiated after studying southwest North Dakota alluvium. Shortly after publication of the Geologic Map of North Dakota (Clayton et al., 1980) distinctive igneous pebbles and cobbles reported on that map to occur in White River Group (Oligocene) sediments and also in sediments labeled as "Quaternary and Upper Tertiary Undivided" caught this author's attention. According to map information these igneous pebbles and cobbles were derived from a Black Hills or a Rocky Mountain source. After studying published literature it became apparent vertebrate paleontologists and others reported a northoriented river had transported the alluvium from the Black Hills to southwest North Dakota. These reports continued even after Denson and Gill (1965) determined no Black Hills igneous rocks matched the distinctive southwest North Dakota igneous rock types and suggested the Beartooth Mountains in south central Montana as the probable source. After personally checking the field evidence and several unsuccessful submission attempts this author was finally able to publish a paper describing his field observations (Clausen, 1989). 
What reviewers repeatedly objected to and had to be deleted before a paper could be published were observations that high energy rivers had transported large quantities of coarse-grained alluvium from the Beartooth Mountain region in a northeast direction to near the Montana-North Dakota border where the river had been at least in part diverted in an east and southeast direction along a continental ice sheet's outer margin, which meant a continental ice sheet had been present when the Oligocene sediments (and fossils) were deposited. According to the accepted geology paradigm there should be a 30 million year time gap between the Oligocene sediments (and fossils) and when the first large North American continental ice sheet was present. Critics severely criticized this author for reporting such an observation and some critics went on to publish papers, which without any supporting evidence continued to advocate the Black Hills as the alluvium source. Eventually this author realized the southwest North Dakota alluvium was anomalous evidence and that a Beartooth Mountain source is inconsistent with accepted geology paradigm predictions so any evidence to the contrary, no matter how good, must be denied or ignored.

Realizing the accepted geology paradigm will never satisfactorily explain certain evidence, such as why a continental ice sheet margin appears to have diverted river(s) transporting alluvium now contained in southwest North Dakota sediments (which also contain well-documented Oligocene fossils), does not lead to a new paradigm. If a new paradigm is to be constructed large quantities of anomalous (or unexplained) evidence are also needed and that evidence was readily available. Many years ago Arthur Strahler, then at Columbia University and Brainerd Mears, then at the University of Wyoming, alerted this author to unexplained erosional landform problems. This author's efforts to explain the previously unexplained erosional landform evidence had led to more and more anomalous evidence until most Northern Great Plains and Rocky Mountain erosional landforms were identified as unexplained or anomalous evidence. The decision was then made to systematically study detailed topographic maps of the entire Missouri River drainage basin with the goal of trying to figure out how the Missouri River drainage basin originated.

\section{Materials and Methods}

That decision led to this author's Missouri River drainage basin landform origins research project during which detailed topographic maps of the entire Missouri River drainage basin and of several adjacent drainage basins were studied to determine how all major drainage divides and many secondary drainage divides had been formed. Drainage divide origins were determined by using divide crossings (through valleys, wind gaps, etc.) as evidence of previous drainage routes and then using barbed tributaries, elbows of capture, asymmetric drainage divides, abandoned head cuts and similar evidence to determine how thousands of capture events altered earlier drainage routes so as to produce present day Missouri River drainage basin drainage routes.

Preliminary work leading to the Missouri River drainage basin landform origins research project was done during the 1980s and 1990s with the project first being done from 1999 to 2001 . The preliminary work and the initial project used large mosaics of hard copy detailed topographic maps and determined that former drainage routes could be reconstructed and had once crossed all major Missouri River drainage divides including the North American east-west Continental Divide. However no strategy to illustrate the detailed topographic map evidence needed to support project conclusions could be found. The entire Missouri River drainage basin was again restudied during the 2011 to 2013 time period using National Geographic TOPO software to again determine origins of all drainage divides within and surrounding the Missouri River drainage basin. All second project research notes with topographic map illustrations pertaining to each of approximately 500 major drainage divides and of approximately 4000 secondary divides, were written as unpublished essays in blog format and are available at geomorphologyresearch.com.

The study reported here demonstrates how a fundamentally new and different paradigm explains how most if not all northern Missouri River drainage basin erosional landforms originated. The new paradigm was constructed by first observing that Missouri River headwaters and tributaries now draining northern Wyoming, central and eastern Montana and much of western North and South Dakota flow down what could be considered to be a northeast-oriented slope. Detailed topographic maps show numerous divide crossings along all major drainage divides between these north- and northeast-oriented Missouri River headwaters and tributary valleys. Orientations and spacing of these divide crossings suggest that prior to Missouri River drainage basin formation a large anastomosing complex of southeast-oriented diverging and converging channels crossed the Missouri River drainage basin, including what are today high mountain areas. This observation led to a second observation supported by stream capture and other evidence that the north-oriented Missouri River headwaters valley and each of its north-oriented tributary valleys had eroded headward across these diverging and converging southeast-oriented channels in a sequential order proceeding from the southeast to the northwest. 
Starting with the above observations the new paradigm was constructed. First the question was asked, "What water source supplied the water responsible for the southeast-oriented diverging and converging channel complex and that then eroded in sequential order from the southeast to the northwest the north- and northeastoriented Missouri River headwaters and tributary valleys?" To answer that question the new paradigm requires the water to have been massive southeastoriented ice-marginal melt-water floods from a large North American continental ice sheet. Second the question was asked "How could continental ice sheet melt-water floods flow over what are today high plateau areas and mountain ranges?" To answer that question the new paradigm requires those plateau areas and mountain ranges to have been uplifted as the large melt-water floods flowed across them. Third the question was asked, "Why did the present day north- and northeast-oriented Missouri River headwaters and tributary valleys erode headward across massive southeast-oriented melt-water floods?" To answer that question the new paradigm requires the continental ice sheet responsible for generating the southeast-oriented floods to have created and occupied a deep "hole" in the North American continent and that as the ice sheet melted space in that deep "hole's" southern end opened up enabling northand northeast-oriented valleys to erode headward across the southeast-oriented floods so as to divert flood waters onto and across the melting ice sheet floor.

Answers to the above questions define the new paradigm, which is a framework of ideas and rules fundamentally different from currently accepted geology discipline paradigm ideas and rules and which is offered here as a new paradigm candidate. What needs to be determined is, does the new paradigm permit better erosional landform origin explanations than the currently accepted geology paradigm? That question can be answered by trying to use the new paradigm to explain specific erosional landform origins. The Missouri River drainage basin contains thousands of previously unexplained (at least in published scientific literature) erosional landforms and while unpublished Missouri River landform origins research project notes in blog format at geomorphologyresearch.com do explain many specific Missouri River drainage basin erosional landform origins only a small number of those erosional landforms have been explained in any published literature. Results described in this paper draw from larger project-related papers published to date for the purpose of demonstrating how the new paradigm provides explanations for previously unexplained, or poorly explained erosional landform origins.

\section{Results}

\section{Explaining Northern Great Plains Landforms}

The Missouri River drainage basin is one of North America's largest drainage basins and any demonstration of the new paradigm's ability to explain specific erosional landform origins must focus on much smaller regions. For that reason this paper focuses on the northeast-oriented regional slope now found in the northern Missouri River drainage basin and piggybacks on ten recently published Missouri River drainage basin landform origins research project-related papers each of which focuses on much smaller regions. The northeastoriented northern Missouri River drainage basin slope is a poorly explained large-scale landform feature. While containing several Rocky Mountain ranges and outliers and intervening structural basins drainage throughout northern Wyoming, central and eastern Montana, and western North and South Dakota flows in north or northeast directions to the east-, southeast- and southoriented Missouri River (see Fig. 1). In western North Dakota the Missouri River flows almost along the North American north-south continental divide. The northern Missouri River drainage basin's western and southwestern boundary is the North American east-west Continental Divide and a case can be made the northeastoriented regional slope is at least in part due to Rocky Mountain uplift, but a case can also be made the northeast-oriented regional slope is in part due to deeper erosion in the northeast than in the southwest. The case for deeper erosion is perhaps best illustrated in North Dakota where the highest point $(1069 \mathrm{~m})$ is near the state's southwest corner and the lowest point $(230 \mathrm{~m})$ is at the state's northeast corner with the Missouri River valley simply being a trench eroded in roughly a northwest-tosoutheast direction across the northeast-oriented slope. A cross section on the Geological Highway Map of North Dakota (Bluemle, 1977) shows an unconformity between glacially deposited sediments and westward dipping Cretaceous, lower Tertiary, and thinner Mesozoic bedrock units. Something created that unconformity and continental ice sheet erosion is a likely candidate.

Figure 1 uses a modified map from the United States Geological Survey (USGS) National Map website to illustrate the Missouri River drainage basin region where the northeast-oriented slope exists. Purple lines show some of the major drainage divides. Blue arrows have been added to emphasize the Missouri River and Missouri River tributaries discussed in the text and are labeled with black letters as follows: M: Missouri River, B: Bighorn River, BF: Belle Fourche River, C: 
Cannonball River, Ch: Cheyenne River, G: Grand River, H: Heart River, J: James River, LM: Little Missouri River, Mo: Moreau River, P: Powder River, T: Tongue River, W: White River, Wi: Wind River and Y: Yellowstone River. With the exceptions of the Missouri River (M) and the James River (J) and possible exception of the White River (W) all of the emphasized drainage routes are described in the literature as having once been components of the north-oriented Bell River system that once drained to the Hudson Bay and Hudson Straits area and then to the Labrador Sea. Dashed brown lines show escarpments discussed in the text. The Missouri Escarpment is labeled in red letters as ME and the Turtle Mountain as TM. The escarpment bounded Prairie Coteau upland is labeled PC and the unlabeled Missouri Coteau is located in North and South Dakota between the Missouri Escarpment and Missouri River. The red letters $\mathrm{CH}$ are located slightly south of the Cypress Hills location, WM shows the Wood Mountain location, FG shows the Flaxville Gravel location and AV shows an abandoned northeast-oriented valley location.

One recent paper (Clausen, 2017a) demonstrates how northeast- and north-oriented western South and North Dakota Missouri River tributary valleys eroded headward across large southeast-oriented floods in an identifiable sequence from the southeast to the northwest. Headward erosion of the Cheyenne River valley captured southeast-oriented flow to the White River drainage basin with the Moreau, Grand, Cannonball, Heart River and Little Missouri River valleys being eroded in that order. The valleys are considered to have eroded headward from space being opened up at the southern end of a deep "hole" that a decaying continental ice sheet had previously created and occupied. Another paper (Clausen, 2017b) describes how the north-oriented Little Missouri River valley and its northeast-oriented Boxelder Creek tributary valley, eroded headward across southeast-oriented floods that had been flowing to the northeast-oriented South Fork Grand River headwaters valley (with the Grand River being an east- and northeast-oriented Missouri River tributary). A third paper (Clausen 2017c) describes how the Sage Creek and Scenic Basins in the South Dakota Badlands area to the east of the Black Hills originated as large headcuts eroded by large southeast-oriented floods (moving to the White River valley) prior to headward erosion of the northeast-oriented Cheyenne River valley. A fourth paper (Clausen, 2018a) shows how northeastoriented Belle Fourche River valley headward erosion in Wyoming's Powder River Basin beheaded and reversed southeast-oriented flood-formed diverging and converging flow channels that had been moving water to the northeast-oriented Cheyenne River headwaters valley.

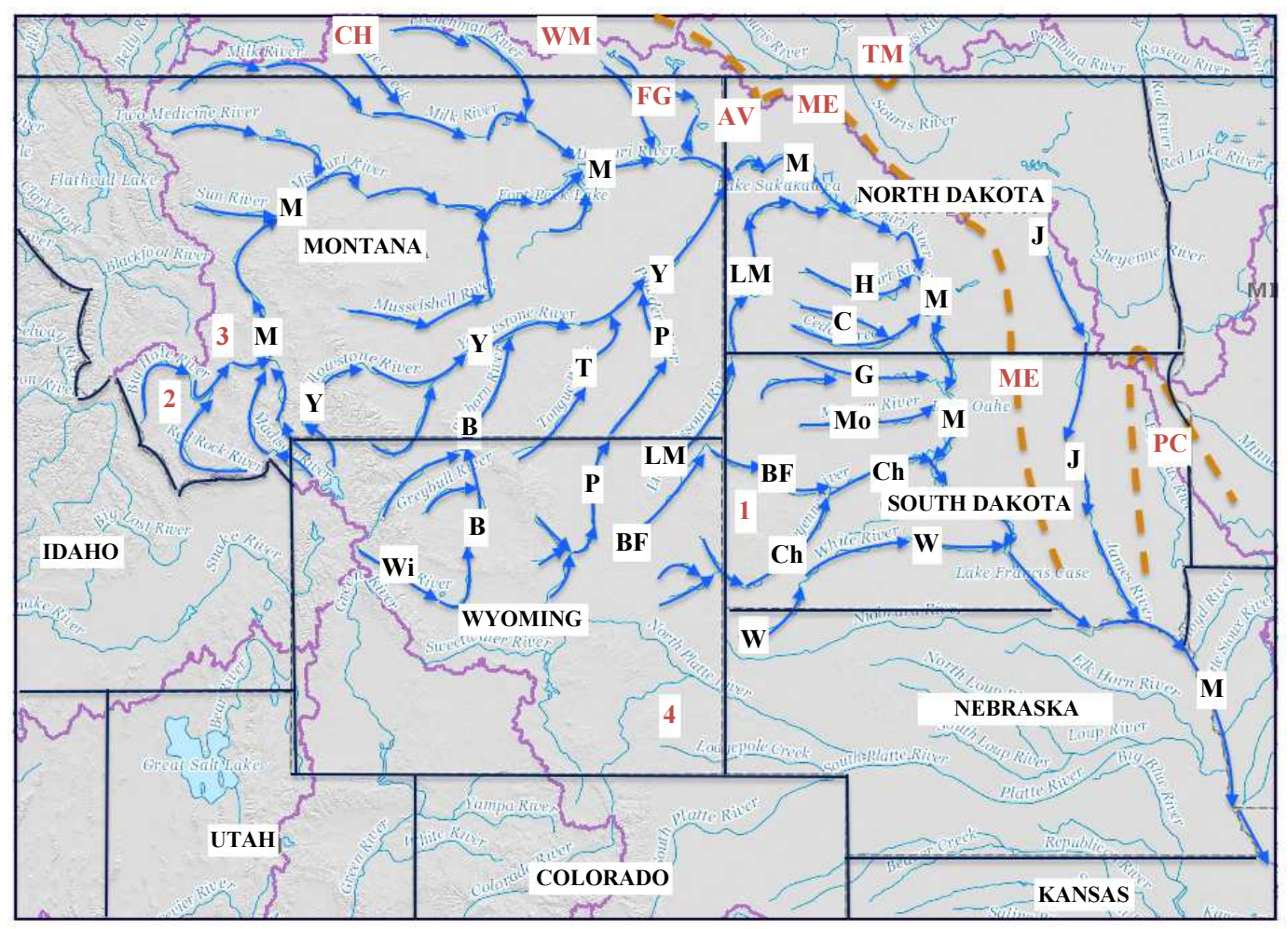

Fig. 1: Modified map from United States Geological Survey (USGS) National Map website showing the northern and western Missouri River drainage basin area. Blue arrows emphasize the Missouri River and Missouri River tributaries discussed in the text. Black letters identify rivers as indicated in the text and red letters identify features and locations as indicated in the text 
More recently in a fifth paper (Clausen, 2018b) illustrates how massive southeast-oriented floods eroded at least $152 \mathrm{~m}$ of bedrock from the Powder River-Little Missouri River drainage divide area near Chalk Buttes in Carter County, Montana prior to headward erosion of the $244 \mathrm{~m}$ deep north-oriented Powder River valley, which occurred after headward erosion of the north-oriented Little Missouri River valley. A sixth recent paper (Clausen 2018c) describes how a melt-water river emerging from the mouth of a large south-oriented ice-walled and bedrock-floored canyon converged with immense southeast-oriented ice-marginal melt-water floods to erode unusual northeast Nebraska drainage routes.

Each of the above mentioned papers demonstrates how large southeast-oriented floods deeply eroded a specific northeast-oriented slope region and also explains the origin of most or all of that region's drainage divides, drainage divide crossing valleys, escarpments, abandoned headcuts, valley orientations, erosional remnants (e.g. buttes), and other erosional landforms. In most cases the erosional landform origin explanations only became possible by viewing the study region's landscape evolution from the context of deep north- or northeast-oriented valleys eroding headward across massive southeast-oriented floods. While geologists and geomorphologists have previously worked in the each of the described study regions their reports usually do not describe how any of the specific erosional landform originated, probably because accepted geology paradigm rules require the north- and northeast-oriented Missouri River tributary valleys to predate North American continental ice sheets. The above-mentioned papers present evidence demonstrating the north- and northeastoriented Missouri River tributary valleys eroded headward across immense southeast-oriented floods of probable continental ice sheet melt water. The papers also show that late during a continental ice sheet's melt history large southeast-oriented floods flowed across Oligocene and Miocene sediments, but do not rule out the possibility those sediments had been previously deposited during earlier stages of that ice sheet's history.

\section{Explaining Black Hills and Rocky Mountain Erosional Landform Origins}

The Missouri River drainage basin includes high mountain areas some of which form the North American east-west Continental Divide. To date geomorphologists abiding by the accepted paradigm rules have not satisfactorily explained the east-west Continental Divide origin or origins for many Rocky Mountain passes, canyons, and other drainage features, probably because accepted geology paradigm rules only permit vague and incomplete explanations. Four additional recently published Missouri River drainage basin landform origins research project-related papers demonstrate how the new paradigm permits mountain pass, canyon, and
Rocky Mountain drainage feature origins to be determined. One of the papers (Clausen, 2018d) demonstrates how streams of southeast-oriented floodwater flowing in diverging and converging channels once crossed what is today one of the Black Hills' highest drainage divides (near location 1 in Fig. 1). The paper interprets the drainage route orientations and drainage divide crossings (through valleys and wind gaps) in the context of tectonic uplift that occurred as immense southeast-oriented floods flowed across the entire region and eroded what was then an emerging Black Hills upland. Evidence presented in the paper also links the southeast-oriented floods that crossed the emerging Black Hills upland with southeast-oriented floods that deeply eroded landscapes found to the east of the Black Hills.

An additional paper (Clausen, 2017d) demonstrates how south-oriented floods of probable continental ice sheet melt water created southwest Montana segments of North America's east-west Continental Divide surrounding what is today the westernmost extent of the Missouri River drainage basin (consisting of the Big Hole and Beaverhead River drainage basins near location 2 in Fig. 1). The paper demonstrates how beginning with immense south-oriented floodwaters flowing from the present day northwest-oriented Clark Fork drainage basin (now draining to the Columbia River and Pacific Ocean) across what are today the high Anaconda Mountains, then across what are today the Big Hole and Beaverhead River drainage basins (now draining to the Missouri River and Gulf of Mexico), and finally across what is today the high Beaverhead Mountain Range the floodwaters reached what is today the Snake River drainage basin (flowing to the Columbia River and Pacific Ocean). The complex Big Hole and Beaverhead River drainage system evolved as these floodwaters eroded what are today high mountain passes notched into what must have been emerging Anaconda, Beaverhead, Pioneer and Centennial Mountain Ranges as deep floodwater erosion and crustal warping created what are today major drainage divides.

Further evidence for immense south-oriented floods of probable continental ice sheet melt water origin across what must have been emerging mountain ranges, including what are today other segments of North America's east-west Continental Divide, is described by still another paper (Clausen, 2017e). That paper explains the origin of mountain passes notched into drainage divides surrounding the Montana Boulder River drainage basin (in Jefferson County near location 3 in Fig. 1). Today the Boulder River begins as a north-oriented river, but makes a U-turn to flow in a south direction before joining the northeast- and east-oriented Jefferson River, which joins two north-oriented rivers at Three Forks, Montana to form the north-oriented Missouri River headwaters. Another of the Missouri River drainage basin landform origins research project-related papers published to date (Clausen, 2018e) demonstrates 
how large floods of possible continental ice sheet meltwater origin flowed across what must have been another emerging mountain range and explain what had been a previously poorly explained bedrock-walled complex of diverging and converging canyons now crossing southeast Wyoming's Laramie Range to the west of the downstream Goshen Hole escarpment-surrounded basin (near location 4 in Fig. 1). Erosional landform origin explanations in each of the four above described mountain regions required mountain ranges to be emerging as large south- and southeast-oriented floods of probable continental ice sheet melt-water origin were flowing across them.

\section{Explaining the Missouri River Location and Unexplained Escarpment Origin Problems}

Few geomorphologists mention in their publications that if the northern Missouri River drainage basin's northeast-oriented slope existed when continental ice sheets reached their maximum extent the North Dakota and South Dakota Missouri River valley is in the wrong place. The Geologic Map of North Dakota (Clayton et al., 1980) and Flint's (1955) study of South Dakota Pleistocene history show the Missouri River valley marks the southern and western limit of abundant and continuous finer-grained glacially deposited sediments, but also show the presence of scattered glacially transported boulders (but without finer-grained glacially deposited sediments) extending as much as $60 \mathrm{~km}$ to the south and west of the Missouri River valley. The scattered glacially transported boulders strongly suggest a continental ice sheet once covered that $60 \mathrm{~km}$ or so of area to the south and west of the modern day Missouri River valley. If so, why is the Missouri River where it is and not $60 \mathrm{~km}$ or so to the south and west?

Approximately 50 to $100 \mathrm{~km}$ to the northeast and east of the North Dakota and South Dakota Missouri River is the northeast- and east-facing Missouri Escarpment (ME on Fig. 1). Between the Missouri Escarpment rim and the Missouri River is an area known as the Missouri Coteau that has been described as a hummocky collapsed or stagnation moraine (e.g., Clayton and Freers, 1967). The Missouri Escarpment and Missouri Coteau end in southern South Dakota where the Missouri River turns in a southeast direction, but continue in a northwest direction from northwest North Dakota across southern Saskatchewan and into Alberta. A similar west-facing escarpment forms the western boundary of the eastern South Dakota and southwestern Minnesota Prairie Coteau upland (PC on Fig. 1) and straddling the North DakotaManitoba border similar escarpments bound the smaller Turtle Mountain upland (TM on Fig. 1). These are a few of what appear to be a large network of similar escarpments that extend across much of southern Saskatchewan and southwest Manitoba. Most of these escarpments bound uplands, which are covered by stagnation moraines similar to the Missouri Coteau, yet glacially deposited sediments are much thinner on the escarpment faces and on lowland floors between the escarpments.

Bluemle (1991) illustrates the problem geomorphologists have when trying to explain erosional landforms such as the Missouri Escarpment by saying, "Before they were glaciated, the Turtle Mountains and Prairie Coteau were erosional outliers - probably low mesas - of Cretaceous and Tertiary sandstone formations that stood above the surrounding plain. ... No really satisfactory explanation has been proposed to explain the presence and prominence of the Missouri Escarpment." Bluemle goes on to say "The Missouri Escarpment is considered to mark the boundary between the Great Plains, on the west and the Central Lowland, on the east. It also separates an extensive area of hummocky collapsed moraine, the Missouri Coteau, from the smoother Glaciated Plains to the east. In places, the rise in elevation across the Missouri Escarpment is as much as 650 feet $[198 \mathrm{~m}]$ in a distance of one or two miles [1.6 or $3.2 \mathrm{~km}$ ], but a less pronounced rise of about 300 to 500 feet [ 91 to $152 / \mathrm{m}$ ] in a distance of two to three miles [3.2 to $4.8 \mathrm{~km}$ ] is more common." Bluemle, like many other geologists, considers the escarpments to be preglacial landscape features, but he does not explain how pre-glacial landscape features carved in easily eroded bedrock survived erosion from what the accepted geology paradigm describes as multiple continental ice sheets.

How does the new paradigm, which requires deep erosion by at least one continental ice sheet, explain the Missouri River location and the Missouri Escarpment, Prairie Coteau, and Turtle Mountain escarpments and the areas of hummocky collapsed moraines on the Missouri Coteau, Prairie Coteau, Turtle Mountains and other escarpment bounded uplands? These and similar landscape features can be used to construct a relatively simple continental ice sheet melt history. The history begins with development of a large Antarctic size continental ice sheet that created and then occupied a deep "hole." The deep "hole" was created by a combination of deep erosion of underlying bedrock and also by crustal warping that gradually raised the Rocky Mountains and Rocky Mountain outliers as continental ice sheet melt-water floods flowed across them. The CLIMAP project (1976) and Marshall et al. (2000) made reconstructions that suggest the continental ice sheet surface reached elevations exceeding $3000 \mathrm{~m}$ with ice thicknesses exceeding $4000 \mathrm{~m}$. Such an ice sheet at its highest points would have stood as high as the highest Rocky Mountain ranges stand today. Paterson (1972) estimated such an ice sheet would have contained about $26.5 \times 10^{5} \mathrm{~km}^{3}$ of ice or the equivalent of a small ocean of water. Such figures probably describe this first large continental ice sheet. 
Present day large-scale landscape features such as the areas of hummocky collapsed moraine and the various escarpments permit a reconstruction of how that first continental ice sheet decayed. As decay progressed large supra-glacial rivers of melt water flowed in south directions across the ice sheet surface and began to slice ice-walled and ice-floored canyons and later ice-walled and bedrock-floored canyons into the decaying ice sheet's surface. These ice-walled and bedrock-floored canyons gradually cut the first ice sheet up into many smaller and isolated or semi-isolated ice sheet masses. The escarpments and some modern day river valleys identify where the large ice-walled and bedrock-floored canyons were once located. One of those supra-glacial melt water rivers, named here as the Midcontinent River, flowed in North Dakota between the Missouri Escarpment and Turtle Mountains. In South Dakota the lowland now occupied by the south-oriented James River (J on Fig. 1) drainage basin and between the eastfacing Missouri Escarpment and west-facing Prairie Coteau escarpment was the south end of a large icewalled and bedrock-floored canyon in which the Midcontinent River flowed. That canyon detached the first ice sheet's southwest margin. Similar ice-walled and bedrock-floored canyons isolated other decaying ice sheet remnants such as those on the present day Prairie Coteau and Turtle Mountain uplands. The Midcontinent River emerged from the decaying ice sheet in southeast South Dakota near where the James River now joins the Missouri River. The Missouri River valley downstream from that point is much wider than to the north and west and that wider valley suggests the downstream Missouri River valley initially eroded headward toward the Midcontinent River's ice-walled and bedrock-floored canyon's mouth before headward erosion of the much narrower upstream Missouri River valley began.

Water emerging from other ice-walled and bedrockfloored canyons also eroded the large Mississippi River valley headward while water from southwest-oriented supra-glacial rivers first moved across the emerging Rocky Mountains, but as crustal warping gradually raised the mountain areas the melt-water floods were forced to flow in a southeast direction toward the actively eroding Missouri River valley. Because this first large ice sheet had created and occupied a deep "hole" the ice-walled and bedrock-floored canyon floors were lower in elevation than the massive southeast-oriented melt-water floods moving toward the actively eroding Missouri River and tributary valley system and in time water from the southeast-oriented floods spilled across the ice sheet's detached and decaying southwest margin to reach the deeper Midcontinent River canyon floor. These spillages enabled northeast- and north-oriented valleys to erode headward from the Midcontinent River canyon floor across the ice sheet's southwest margin and then across the southeast-oriented melt-water floods and to systematically divert the southeast-oriented floodwaters onto the decaying ice sheet floor.
At first the diverted floodwaters joined the southeastand south-oriented Midcontinent River and eventually reached the Gulf of Mexico. However, in time the icewalled and bedrock-floored canyon network opened up new routes so the diverted floodwaters could reach the present day Saint Lawrence River drainage basin and later could flow to the Hudson Bay and Hudson Straits areas and then to the Labrador Sea. These massive meltwater flood diversions eroded the valleys in what the accepted paradigm describes as the pre-glacial Bell River system. The large-scale diversion of melt-water floods from the south to the north also triggered a major climate change. Climates produced when immense southoriented melt-water floods entered the Gulf of Mexico accelerated the first ice sheet's rapid melting, but climates produced when those floodwaters entered the Labrador Sea not only ended the first ice sheet's rapid melting, but also froze the north-oriented melt-water floods and other drainage so the incoming north-oriented water filled the former ice-walled and bedrock-floored canyons and kept freezing so as to create a second ice sheet.

The second ice sheet consisted of newly frozen water surrounding what had been detached first ice sheet remnants. Present day areas of hummocky collapsed moraine such as the Missouri Coteau and the Prairie Coteau and Turtle Mountain uplands are where the first ice sheet remnants were located and lowlands between the present day escarpments are where the frozen incoming north-oriented water was located. Ponded incoming water froze from the top down, which meant liquid water and/or water-saturated bedrock was still present under some of the frozen ponded water. This basal liquid water and water-saturated bedrock played a significant role in developing ice-thrust topographic features described by Bluemle and Clayton (1984). The present day Missouri Coteau represents what was left of the first ice sheet's southwest margin at the time first ice sheet melting ceased. As a result when freezing of northoriented water blocked the newly created north-oriented drainage system new drainage moving down the newly created northeast-oriented slope was forced to flow along what is now the Missouri Coteau's southwest margin as the water spilled from one previously eroded valley segment to another so as to erode the ice-marginal Missouri River valley right where it is today.

Compared with the first continental ice sheet the second ice sheet was much thinner and did not deeply erode the underlying bedrock. For much of the second ice sheet's history first ice sheet remnants embedded in the more mobile wet-based frozen ponded water probably remained as debris-covered stagnant ice masses. Rapid isostatic uplift in response to the first ice sheet's melting caused movements in more mobile wetbased frozen ponded water areas of the second ice sheet that raised attached frozen bedrock masses and otherwise shaped or reshaped underlying bedrock and first ice sheet transported materials. The climate change that 
produced the second ice sheet was also responsible for alpine glaciers in higher Rocky Mountain regions, which first ice sheet related crustal warping had elevated. It is possible second ice sheet melting produced oscillating climates with warmer climates developing when melt water flowed in south directions and colder climates returning as ice sheet melting opened up melt water flow routes to the north. If so the north-oriented melt-water and other drainage could have again frozen to produce another thin ice sheet and the process could have been repeated multiple times. Eventually only the debris covered (and insulated) first ice sheet remnants remained and those debria covered (and insulated) first ice sheet remnants melted slowly to produce what are today areas of hummocky collapsed moraine.

\section{Some Further Clues as to How the Continental Ice Sheet Melted}

Several alluvium covered continental ice sheet margin erosional remnants may provide additional clues as to how the first ice sheet melted. Because the decaying ice sheet was located in a deep "hole" areas to the south and west of the ice sheet margin were at a significantly higher elevation than the deep "hole" floor and present day ice-marginal erosional remnants may document how the ice sheet melted. The Cypress Hills (slightly north of $\mathrm{CH}$ on Fig. 1) along the AlbertaSaskatchewan border and along the Gulf of MexicoHudson Bay (Missouri River-Saskatchewan River) drainage divide represent one such group of erosional remnants. The Cypress Hills are buttes or flat topped uplands now standing up to $1466 \mathrm{~m}$ above sea level, or about 300-500 $\mathrm{m}$ above the surrounding plains and are capped by thick coarse-grained alluvial deposits containing Oligocene and other mid and late Tertiary fossils. Evidence of Late Wisconsin glaciation is found along the Cypress Hills flanks, but not on the Cypress Hills upper surface (Kulig, 1996). Further to the east in southern Saskatchewan another such ice-marginal erosional remnant is Wood Mountain (WM on Fig. 1) rising to slightly more than $1000 \mathrm{~m}$, or $200-400 \mathrm{~m}$ above the surrounding plains. Alluvial deposits containing Miocene and other age fossils cap the Wood Mountain upland surface (Leckie et al., 2004). To the southeast in northeast Montana the Flaxville gravels (FG on Fig. 1) contain late Miocene or early Pliocene fossils (Brown, 1952) and cover a high level surface that has an elevation of about $850 \mathrm{~m}$ and which is approximately $100 \mathrm{~m}$ above the surrounding plains. Further to the east is a large abandoned valley (AV on Fig. 1) that crosses the Missouri Coteau and Escarpment (sometimes referred to the pre-glacial Missouri River valley).

There is no question, no matter which paradigm is used, that these erosional remnants and the abandoned valley document different stages in the regional erosion history. From the accepted paradigm perspective the
Cypress Hills upper surface can be interpreted to be the prevailing Oligocene surface. Such an interpretation sees the Wood Mountain alluvium deposited on the prevailing Miocene surface and the Flaxville gravels deposited on the prevailing Pliocene surface with the abandoned valley being eroded prior to Pleistocene glaciation. However, no good explanation exists as to why thick deposits of coarse-grained alluvium accumulated at the Cypress Hills, Wood Mountain, and Flaxville gravel locations.

From the new paradigm perspective those three erosional remnants and the abandoned valley can be viewed as recoding stages in the first continental ice sheet's melt history. The previously mentioned Missouri Escarpment is located 75 to $150 \mathrm{~km}$ to the north and east of the three erosional remnants and the abandoned valley cuts across the Missouri Escarpment face. The Missouri Escarpment as previously mentioned is what remains of a large southeast-oriented ice-walled and bedrockfloored canyon's (sliced by the Midcontinent River) southwest and west wall, although before developing its bedrock floor that canyon had an ice floor. At some point as the ice sheet melted the canyon's ice floor elevation became low enough so melt-water floods flowing on higher elevation ice-marginal areas to the south and west of the decaying ice sheet could flow back onto the ice sheet surface and into the deeper Midcontinent River canyon. The thick alluvium deposits were produced by seasonal blockages at points where the diverted melt-water floods flowed back onto the ice sheet surface. The three erosional remnants and the abandoned valley may simply record how the route of one northeast-oriented Midcontinent River tributary migrated in a downstream direction as the first ice sheet melted and the massive melt-water floods lowered the adjacent ice-marginal surface.

\section{Discussion}

Paradigms according to Thomas Kuhn (1962) are fundamentally different frameworks of ideas and rules governing a discipline's research efforts and one paradigm cannot be judged from another paradigm's perspective. Instead paradigms must be evaluated on their ability to explain evidence and to lead researchers to new research opportunities. The accepted geology paradigm has been extremely productive in explaining at least some evidence and in leading researchers to at least some new research opportunities. Yet as described here and in the ten cited Missouri River drainage basin landform origins research project-related papers the accepted geology paradigm does not permit satisfactory explanations for many erosional landform origins. As a result the recent geomorphology literature seldom addresses specific erosional landform origins, such as origins of specific drainage divides, divide crossing valleys, mountain passes, stream captures, barbed 
tributaries, valley orientations, and drainage basins. These and other ignored erosional landforms exist and must be considered if complete and correct regional geologic histories are to be written. As explained in this paper the new paradigm investigated here requires at least one North American continental ice sheet to have created and occupied a deep "hole" by a combination of deep ice sheet related erosion and as ice sheet related crustal warping raised mountain ranges and plateaus. Further the new paradigm requires immense melt-water floods to have flowed from that continental ice sheet and deep erosion of regions those floodwaters crossed.

One unexpected new paradigm implication that may be difficult for many in the geology research community to accept is the possibility the two somewhat linked continental ice sheets described here may explain all northern Missouri River drainage basin erosional landform origins and may also explain many if not all of the previously mapped northern Missouri River drainage basin Oligocene, Miocene, Pliocene and Pleistocene sediments. Warm climates caused the first ice sheet to melt so the existence of warm climate animals and vegetation near the melting ice sheet margin does not contradict such a possibility. But more troublesome is what happens to the approximately 30 million years the accepted geology paradigm sees as existing between the Oligocene and the Pleistocene? Interpretations made in this paper and in the ten cited new paradigm demonstration papers are based on relative ages and no effort has been made to link those interpretations with absolute ages. But does it take 30 million years to create and then to melt a continental ice sheet and did the second much thinner ice sheet last for another 2 or 3 million years? Or have geologists using the accepted geology paradigm constructed a geologic time scale with too much middle and late Cenozoic absolute time? Failure to recognize deep erosion by at least one continental ice sheet and to explain Missouri River drainage basin erosional landform origins may have been a serious mistake that may force the geologic research community to significantly rewrite important components of what are today commonly accepted middle and late Cenozoic geologic and glacial histories.

\section{Conclusion}

Several observations should stand out to readers of this paper. First is the new paradigm, at least in the regions where it has been demonstrated to date, has the ability to explain previously unexplained erosional landform origins. Headward erosion of deep valleys across immense melt-water floods provide much better erosional landform origin explanations than trying to explain erosional landform origins using such factors as long periods of time, climatic change and "normal" erosion. However, when interpreted from the new paradigm perspective northern Missouri River drainage basin erosional landforms provide a fundamentally different glacial history interpretation than that constructed from the accepted geology paradigm perspective. Perhaps most significant at least from the evidence presented here is only two somewhat linked continental ice sheets explain most if not all northern Missouri River drainage basin erosional landform origins, yet glacial histories as determined from the accepted paradigm perspective describe multiple glacial and interglacial episodes. Further the geologic history constructed when erosional landform origins are interpreted from the new paradigm perspective almost certainly will require a fundamentally different interpretation of at least some Oligocene, Miocene and Pliocene sediments (and fossils) than the current geologic literature provides. In other words deep erosion by continental ice sheets does explain northern Missouri River drainage basin erosional landforms, but it also results if a fundamentally different interpretation of middle and late Cenozoic geologic and glacial history than the geologic research community has developed to date.

\section{Acknowledgement}

Early work that led to the Missouri River drainage basin landform origins research project and to this paper was done while employed as a faculty member at Minot State University (North Dakota) where other faculty members and library staff members assisted in developing and providing access to needed topographic map collections.

\section{Ethics}

This article is original and contains previously unpublished materials. The author confirms there are no ethical issues involved.

\section{References}

Bell, M. and E. Laine, 1985, Erosion of the Laurentide region of North America by glacial and glaciofluvialprocesses. Quaternary Res. 23: 154-174.

Bluemle, J.P. and L. Clayton, 1984. Large-scale glacial thrusting and related processes in North Dakota. Boreas, 13: 279-299.

Bluemle, J.P., 1977. Geological highway map of North Dakota: North Dakota geological survey educational series 11. Miscellaneous Map 19.

Bluemle, J.P., 1991. The face of North Dakota. 1st Edn., North Dakota Geological Survey, Educational Series 21, pp: 178.

Boulton, G.S., 1987. Progress in glacial geology during the last fifty years. J. Glaciology.

Brown, R.W., 1952. Tertiary strata in eastern Montana and western North Dakota and South Dakota, Proceedings of the 3rd Annual Field Conference Billings Geological Society Guidebook, (BGSG'52), pp: 89-92. 
Clark, P.U. and D. Pollard, 1998. Origin of the middle Pleistocene transition by ice sheet erosion of regolith. Paleoceanography, 13: 1-9.

Clausen, E., 1989. Presence of rounded boulders and large cobbles at base of White River Group (Oligocene) strata in southwest North Dakota and northwest South Dakota. Contributions Geology, 27: $1-6$.

Clausen, E., 2017a. Using map interpretation techniques for relative dating to determine a western North Dakota and South Dakota drainage basin formation sequence, Missouri River drainage basin, USA. J. Geography Geology, 9: 1-18.

Clausen, E., 2017b. Origin of Little Missouri River South Fork Grand River and nearby Drainage Divides in Harding County, South Dakota and Adjacent Eastern Montana, USA. Open J. Geology, 7: 1063-1077.

Clausen, E., 2017c. Solving a perplexing Scenic and Sage Creek drainage history problem, Pennington, County, South Dakota, USA. J. Geography Geology, 9: 1-10.

Clausen, E., 2017d. Origin of mountain passes across Continental Divide segments surrounding the southwest Montana Big Hole and Beaverhead River drainage basins, USA. Open J. Geology, 7: 1362-1385.

Clausen, E., 2017e. Analysis of mountain passes along the east-west Continental Divide and other drainage divides surrounding the Boulder River drainage basin, Jefferson County, Montana, USA. Open J. Geology, 7: 1603-1624.

Clausen, E., 2018a. Belle Fourche River-Cheyenne River drainage Divide area in the Wyoming Powder River Basin analyzed by topographic map interpretation methods, USA. J. Geography Geology, 10: 1-16.

Clausen, E., 2018b. Probable deep erosion by continental ice sheet melt water floods: Chalk Buttes area of Carter County, Montana, USA. Int. J. Geography Geology, Conscientia Beam, 7:14-26.

Clausen, E., 2018c. Interpreting topographic map evidence related to northeast Nebraska barbed tributaries and drainage routes, USA. J. Geography Geology, 10: 66-79.

Clausen, E., 2018d. Topographic map analysis of high elevation Black Hills through valleys linking Spearfish and Rapid Creek headwaters valleys, Lawrence County, South Dakota, USA. J. Geography Geology, 10: 8-21.

Clausen, E., 2018e. Topographic map analysis of Laramie Range bedrock-walled canyon complex and the Goshen Hole escarpment-surrounded basin, Albany and Platte Counties, southeast Wyoming, USA. Open J. Geology, 8: 33-55.
Clayton, L. and T.F. Freers, 1967. Glacial Geology of the Missouri Coteau: North Dakota Geological Survey. Miscellaneous Series.

Clayton, L. J.P. Bluemle and C.G. Carlson, 1980. Geologic map of North Dakota: North Dakota Geological Survey.

CLIMAP Project Members, 1976. The surface of the IceAge Earth. Science, 191: 1131-1137.

Cummings, D.I., A.J.R. Hazen and D.R. Sharp, 2012, Buried-valley aquifers in the Canadian prairies: Geology, hydrogeology and origin. Canadian J. Earth Sci., 49: 987-1004.

Denson, N.M. and J.R. Gill, 1965. Uranium-bearing lignite and carbonaceous shale in the southwestern part of the Williston Basin-a regional study. United States Geological Survey Professional Paper.

Duk-Rodkin, A. and O.L. Hughes, 1994. TertiaryQuaternary drainage of the pre-glacial MacKenzie River basin. Quaternary Int., 22-23: 221-241.

Flint, R.F., 1955. Pleistocene geology of eastern South Dakota. United States Geological Survey Professional Paper.

Flint, R.F., 1971. Glacial and Quaternary Geology. 1st Edn., John Wiley \& Sons, Inc., New York, pp: 892.

Fredin, O., G. Viola, H. Zwingmann and R. Sarlie, 2017. The inheritance of a Mesozoic landscape in western Scandinavia. Nature Communications, 8: 14879.

Kuhn, T.S., 1962. The Structure of Scientific Revolutions, 2nd Edn., The University of Chicago Press, pp: 210.

Kulig, J.J., 1996. The glaciation of the Cypress Hills of Alberta and Saskatchewan and its regional implications. Quaternary Int., 32: 53-77.

Laine, E.P., 1980. New evidence from beneath the western North Atlantic for the depth of glacial erosion in Greenland and North America. Quaternary Res., 14: 188-98.

Leckie, D.A., J.M. Bednarski and H.R. Young, 2004. Depositional and tectonic setting of the Miocene Wood Mountain Formation, southern Saskatchewan. Canadian J. Earth Sci., 41: 1319-1328.

Licciardi, J.M., P.U. Clark, J.W. Jenson and D.R. Macayeal, 1998. Deglaciation of a soft-bedded Laurentide Ice Sheet. Quaternary Sci. Rev., 17: 427-448.

Marshall, S.J., L. Tarasov, K.C. Clarke and W.R. Peltier, 2000. Glaciological reconstruction of the Laurentide Ice Sheet: Physical processes and modeling challenges. Canadian J. Earth Sci., 37: 769-793.

McMillan, J.N., 1973. Shelves of the Labrador Sea and Baffin Bay, Canada. Canadian Society Petroleum Geologists Memoir, 1: 473-515.

Paterson, W.S.B., 1972. Laurentide ice sheet: Estimated volumes during Late Wisconsin: Reviews Geophysics, 10: 885-917. 
Sears, J.W., 2013. Late Oligocene-early Miocene Grand Canyon: A Canadian connection? GSA Today, 23: 4-10.

Sugden, 1978. Glacial erosion by the Laurentide Ice Sheet. J. Glaciology, 20: 367-391.

Sugden, D. E., 1976. A case against deep erosion of shields by continental ice sheets. Geology, 4: 580-582.
Thornbury, W.D., 1965. Regional Geomorphology of the United States, 1st Edn., John Wiley and Sons, New York, pp: 609.

United States Geological Survey (USGS), National Map. White, W.A., 1972. Deep erosion by continental ice sheets. Geological Society Am. Bulletin, 83: 1037-1056. 